\title{
Microbial Controls on Methane Fluxes from a Polygonal Tundra of the Lena Delta, Siberia
}

\author{
D. Wagner, * S. Kobabe, E.-M. Pfeiffer and H.-W. Hubberten
}

Alfred Wegener Institute for Polar and Marine Research, Potsdam, Germany

\begin{abstract}
Permafrost soils of high-latitude wetlands are an important source of atmospheric methane. In order to improve our understanding of the large seasonal fluctuations of trace gases, we measured the $\mathrm{CH}_{4}$ fluxes as well as the fundamental processes of $\mathrm{CH}_{4}$ production and $\mathrm{CH}_{4}$ oxidation under in situ

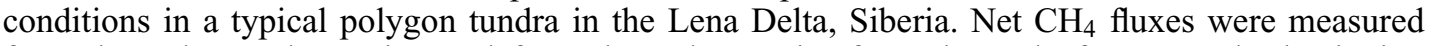
from the polygon depression and from the polygon rim from the end of May to the beginning of September 1999. The mean flux rate of the depression was $53.2 \pm 8.7 \mathrm{mg} \mathrm{CH}_{4} \mathrm{~m}^{-2} \mathrm{~d}^{-1}$ with maximum in mid-July $\left(100-120 \mathrm{mg} \mathrm{CH}_{4} \mathrm{~m}^{-2} \mathrm{~d}^{-1}\right)$, whereas the mean flux rate of the dryer rim part of the polygon was $4.7 \pm 2.5 \mathrm{CH}_{4} \mathrm{~m}^{-2} \mathrm{~d}^{-1}$. The microbial $\mathrm{CH}_{4}$ production and oxidation showed significant differences during the vegetation period. The $\mathrm{CH}_{4}$ production in the upper soil horizon of the polygon depression was about 10 times higher $\left(38.9 \pm 2.9 \mathrm{nmol} \mathrm{CH}_{4} \mathrm{~h}^{-1} \mathrm{~g}^{-1}\right)$ in July than in August $\left(4.7 \pm 1.3 \mathrm{nmol} \mathrm{CH}_{4} \mathrm{~h}^{-1} \mathrm{~g}^{-1}\right)$. The $\mathrm{CH}_{4}$ oxidation behaved exactly in reverse: the oxidation rate of the upper soil horizon was low $\left(1.9 \pm 0.3 \mathrm{nmol} \mathrm{CH}_{4} \mathrm{~h}^{-1} \mathrm{~g}^{-1}\right)$ in July compared to the activity in August (max. $7.0 \pm 1.3 \mathrm{nmol} \mathrm{CH}_{4} \mathrm{~h}^{-1} \mathrm{~g}^{-1}$ ). The results indicated clearly an interaction between the microbiological processes with the observed seasonal $\mathrm{CH}_{4}$ fluctuations. However, the $\mathrm{CH}_{4}$ production is primarily substrate dependent, while the oxidation is dependent on the availability of oxygen. The temperature plays only a minor role in both processes, probably because the organisms are adapted to extreme temperature conditions of the permafrost. For the understanding of the carbon dynamics in permafrost soils, a differentiated small-scale view of the microbiological processes and the associated modes of $\mathrm{CH}_{4}$ fluxes is necessary, especially at key locations such as the Siberian Arctic. Copyright (C) 2003 John Wiley \& Sons, Ltd.
\end{abstract}

KEY WORDS: methane fluxes; microbial processes; $\mathrm{CH}_{4}$ production; $\mathrm{CH}_{4}$ oxidation; permafrost soils

\section{INTRODUCTION}

Wet tundra environments of the Arctic influence the global climate by the release of methane $\left(\mathrm{CH}_{4}\right)$ and other radiatively active trace gases into the atmosphere. Methane contributes to the enhanced greenhouse effect with a portion of approximately 20\% (Wuebbles and Hayhoe, 2002). The world-wide

* Correspondence to: D. Wagner, Alfred Wegener Institute for Polar and Marine Research, Telegrafenberg A 43, 14473 Potsdam, Germany. E-mail: dwagner@awi-potsdam.de

Copyright $@ 2003$ John Wiley \& Sons, Ltd. wetland area has a size of about $5.5 \times 10^{6} \mathrm{~km}^{2}$ (Aselman and Crutzen, 1989), about half of it is located in high latitudes of the northern hemisphere $\left(>50^{\circ} \mathrm{N}\right)$. The atmospheric input of methane from tundra soils of this region has been estimated between 20-40 Tg $\mathrm{CH}_{4} \mathrm{yr}^{-1}$ (Christensen et al., 1996), corresponding to about $25 \%$ of the methane emission from natural sources (Fung et al., 1991). However, the strength of tundra environments as a methane source and the sensitivity of permafrost to potential changes in climate are still uncertain. 
In the last decades numerous studies on methane fluxes were focused on tundra environments in Northern America and Scandinavia (e.g. Svensson and Rosswall, 1984; Whalen and Reeburgh, 1988; Bartlett et al., 1992; Liblik et al., 1997; Reeburgh et al., 1998; Christensen et al., 2000). Since the early nineties, the large tundra areas of Russia were integrated into these investigations (e.g. Christensen et al., 1995; Samarkin et al., 1999; Panikov and Dedysh, 2000; Tsuyuzaki et al., 2001). All these studies reveal temporal and spatial variability of methane fluxes, ranging between -1.9 and $360 \mathrm{mg} \mathrm{CH}_{4} \mathrm{~m}^{-2} \mathrm{~d}^{-1}$. To understand these dramatic fluctuations, some studies focused on the environmental conditions and soil characteristics. Water table position, soil moisture and temperature, type of substrate and vegetation as well as availability of organic carbon, which indirectly influences the methane dynamics of tundra environments, were studied (e.g. Torn and Chapin, 1993; Vourlitis et al., 1993; Bubier et al., 1995; Oberbauer et al., 1998; Joabsson et al., 1999; Yavitt et al., 2000). Although $80-90 \%$ of total methane emission originates from microbial activities (Ehhalt and Schmidt, 1978), only a few investigations dealt with methane production and methane oxidation caused by basically microbiological processes (Slobodkin et al., 1992; Vecherskaya et al., 1993; Samarkin et al., 1994; Schimel and Gulledge, 1998; Segers, 1998; Frenzel and Karofeld, 2000; Wagner et al., 2001).

Approximately $14 \%$ of the global carbon is stored in permafrost soils and sediments (Post et al., 1982). Due to this carbon pool, tundra environments play a major role in the global carbon cycle, even more since current climate models predict significant changes in temperature and precipitation patterns in these regions (Hansen et al., 1988; Kattenberg et al., 1996). The microbial methane production (methanogenesis) is one of the most prominent microbiological processes during the anaerobic decomposition of organic matter. A small group of strictly anaerobic organisms called methanogenic archaea is responsible for methanogenesis (Garcia et al., 2000). Although methanogenic archaea are widespread in nature (e.g. permafrost soils, marshes, swamps, marine and freshwater sediments, flooded rice paddies, geothermal habitats), they show an extremely specialized metabolism. In permafrost soils two main pathways of energy-metabolism dominate: (i) the reduction of $\mathrm{CO}_{2}$ to $\mathrm{CH}_{4}$ using $\mathrm{H}_{2}$ as a reductant and (ii) the fermentation of acetate to $\mathrm{CH}_{4}$ and $\mathrm{CO}_{2}$ (Deppenmeier et al., 1996).

After its production methane is partly oxidized either in the aerobic top layer of permafrost soils or in the aerobic rhizosphere by highly specialized Proteobacteria, belonging to the group of methanotrophic bacteria (Hanson and Hanson, 1996). They are using $\mathrm{CH}_{4}$ as the sole carbon source, while energy is gained by the oxidation of $\mathrm{CH}_{4}$ to $\mathrm{CO}_{2}$. Methanotrophic bacteria are common in almost all environments, where they can survive under unfavourable living conditions by the formation of spores. The oxidation of methane by methanotrophic bacteria as a sink for methane is probably just as important as the production of methane by methanogenic archaea. Both processes determine the methane fluxes of natural wetlands. It is well known that the methane oxidation in rice soils amounts to $45-90 \%$ and in freshwater ecosystems to $80-90 \%$ of the produced methane (Frenzel et al., 1990; van Bodegom et al., 2001; Khalil et al., 1998). Thus a better understanding of methane fluxes of natural wetlands requires the knowledge of the function, physiology and population dynamics of the involved microorganisms.

The purpose of this study was to verify the role of the microbial processes for the seasonal fluctuation of methane fluxes from tundra environments. The analysis included measurements of seasonal methane fluxes and environmental parameters as well as the quantification of methane production and oxidation under in situ conditions within the active layer of permafrost soils.

\section{STUDY SITE}

The study site of Samoylov Island, Siberia, lies within the Lena Delta, which represents the largest delta of the circum-arctic land masses, formed by the Lena River. The Lena Delta is located at the Laptev Sea coast between the Taimyr Peninsula and the New Siberian Islands (Figure 1). The delta occupies an area of about $32,000 \mathrm{~km}^{2}$ and is characterized by a network of smaller and larger rivers and channels as well as more than 1500 islands. The delta can be divided into three geomorphologically different terraces (Are and Reimnitz, 2000; Schwamborn et al., 2002): (i) the oldest terrace was formed in the middle to late Pleistocene and is fragmentarily exposed (30-55 $\mathrm{m}$ a.s.1.) in the southern part of the delta. The terrace consists of ice-complexes containing fine-grained silty sediments with a high content of segregated ice. The ice-complex moreover includes enormous layers of organic-rich material and less decomposed peaty material, (ii) Arga Island, the western part of the delta $(20-30 \mathrm{~m}$ a.s.1.) is characterized by coarse-grained sandy sediments and a multitude of deep lakes, which were formed in 


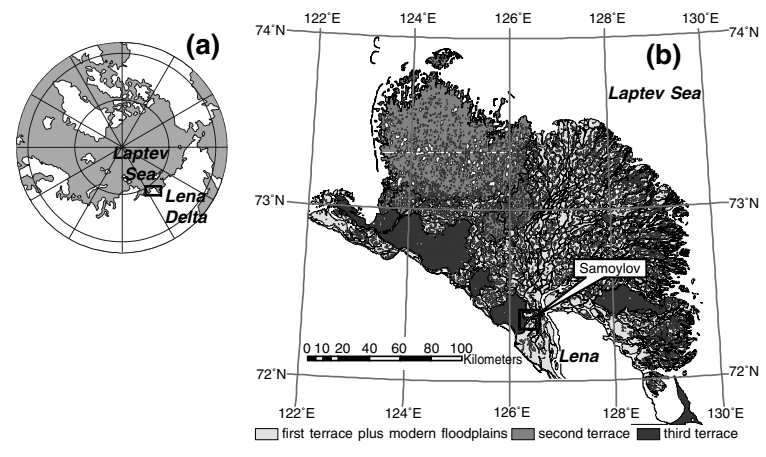

Figure 1 Map showing the Lena Delta, northeast Siberia (N $72^{\circ} 22$, E $126^{\circ} 28$ ). (a) circum polar map with the details of the Lena Delta; (b) location of the study area Samoylov Island within the Lena Delta.

the late Pleistocene to late Holocene, (iii) the eastern terrace is regarded as the currently active part of the Lena Delta. The latter is of a middle Holocene age with several modern flood plains (1-12 $\mathrm{m}$ a.s.1.) at the base. The landscape of the delta is characterized by the patterned ground of ice-wedge polygons in different development stages (Müller, 1997). The entire delta is situated in the zone of continuous permafrost with a thickness of about $500-600 \mathrm{~m}$ (Romanovskii and Hubberten, 2001).

Samoylov (N $72^{\circ} 22$, E $126^{\circ} 28$ ) is a representative island in the active and youngest part (8000-9000 years) of the Lena Delta and covers an area of about 1200 ha. The western coast of the island is characterized by modern accumulation processes (fluvial and aeolian sedimentation). Three flood plains can be distinguished, which differ in their flooding frequency and vegetation coverage.
The texture of accumulated sediments is dominated by the sand fraction (fine to medium). In contrast, the eastern coast of Samoylov is dominated by erosion processes, which form an abrasion coast. This part is composed of middle Holocene deposits, which cover about $70 \%$ of the total area of the island. Our studies of methane fluxes and microbial activity were carried out within this terrace, which is dominated by active ice wedges with low-centred polygons. The topography is determined by this patterned ground and shows a distinct micro-relief of polygon rims and polygon depressions.

Due to the micro-relief, soil and vegetation characteristics vary in rapid succession. The soils of the investigation site are characterized by very homogeneously spread soil units: the polygon rims were dominated by Glacic Aquiturbels (Ajj, Bjjg, Bjjf), whereas the prevalent soil type of the polygon depressions were Typic Historthels (Oi, A, Bg, Bf) classified according to the US Soil Taxonomy (Soil Survey Staff, 1998). The peaty soils of the polygon depression are characterized by a water level near the soil surface and the predominantly anaerobic accumulation of organic matter. The drier soils of the polygon rim show a distinctly deeper water level, lower accumulation of organic matter and pronounced cryoturbation properties. The vegetation of the polygon rim is dominated by dwarf shrub Dryas punctata and the mosses Hylocomium splendens and Timmia austriaca, whereas the polygon depression is dominated by hydrophytes like various Carex species and different moss species (e.g. Limprichtia revolvens, Meesia longiseta). The thaw depth of the soils varied between 30 and $45 \mathrm{~cm}$ (rim, depression), respectively. A typical cross-section of a low-centred polygon is shown in Figure 2.

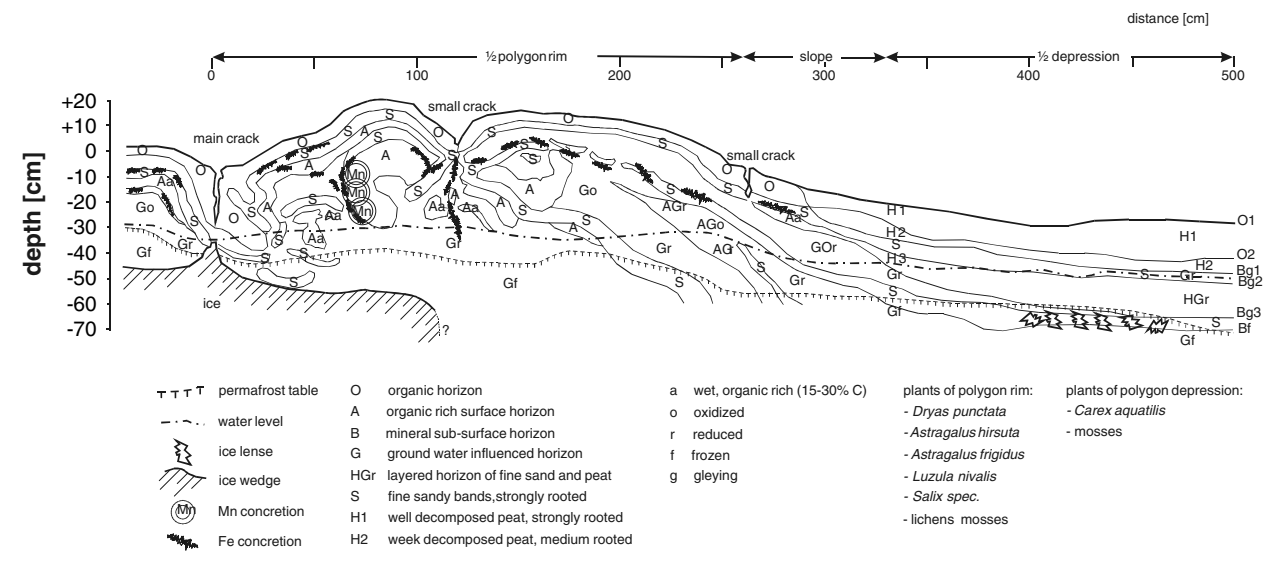

Figure 2 Cross section, across the border, of a typical low-centered polygon (Lena Delta, Siberia). 
The climate of the southern Lena Delta is characterized by a low mean annual air temperature $\left(-14.7^{\circ} \mathrm{C}\right)$ and a mean annual precipitation of $190 \mathrm{~mm}$. The winter season lasts nine months, from the end of September to the end of May $\left(\mathrm{T}_{\mathrm{avg}}=\right.$ $-30{ }^{\circ} \mathrm{C}, \mathrm{T}_{\min }=-48^{\circ} \mathrm{C}$ ) with insufficient light (polar night) and heavy snowstorms $\left(140 \mathrm{~km} \mathrm{~h}^{-1}\right.$, Wein, 1999). The summer period of almost 12 weeks is characterized by higher temperatures $\left(\mathrm{T}_{\mathrm{avg}}=7^{\circ} \mathrm{C}\right.$, $\mathrm{T}_{\max }=18^{\circ} \mathrm{C}$ ) and permanent light (polar day).

\section{MATERIAL AND METHODS}

\section{$\mathrm{CH}_{4}$ Fluxes}

$\mathrm{Net} \mathrm{CH}_{4}$ fluxes presented in this paper were measured from the end of May to the beginning of September during the Expedition LENA 1999 (Pfeiffer et al., 2000). This investigation pertained to an ongoing long-term study of trace gas emissions, which started in 1998. The flux measurements were determined using five static chambers (PVC transparent, 12.5 1) for the polygon rim and depression, respectively. The chambers consisted of a $50 \times 50 \mathrm{~cm}$ stainless steel base installed permanently $15 \mathrm{~cm}$ into the active layer. Water filled channels on top of the steel base provided airtight seals of the chamber components. Each chamber was fitted with four ports connected with two perforated pipes fixed inside the chamber. Chamber headspace was sampled over $30 \mathrm{~min}$ by pumping headspace air through a gas collecting jar connected with gastight tubes (Tygon). $\mathrm{CH}_{4}$ fluxes were calculated from the chamber volume and the linear increase in $\mathrm{CH}_{4}$ concentration.

Vertical profiles of soil $\mathrm{CH}_{4}$ concentrations were obtained from both the polygon rim and depression by extracting $\mathrm{CH}_{4}$ from soil pore water. Fresh soil (about $20 \mathrm{~g}$ ) from each horizon was placed immediately after sampling into $50-\mathrm{ml}$ glass jars containing $35 \mathrm{ml}$ of saturated $\mathrm{NaCl}$ solution. Jars were closed gastight with a screw cap with septum, equilibrated by shaking the solution and analysed for $\mathrm{CH}_{4}$ concentration by taking a sample with a gastight syringe from the jars headspace.

\section{$\mathrm{CH}_{4}$ Production and Oxidation}

The $\mathrm{CH}_{4}$ production and oxidation capacity of the soil typical for the polygon depression was analysed at the beginning of July and at the beginning of August 1999, while the microbial activity of the soil from the polygon rim was measured only in August 2000 .
The $\mathrm{CH}_{4}$ production was studied considering the in situ soil temperature gradient. Fresh soil material $(20 \mathrm{~g})$ from different soil horizons was weighed into $100-\mathrm{ml}$ glass jars and closed with a screw cap containing a septum. The samples were evacuated and flushed with ultra pure $\mathrm{N}_{2}$. The prepared soil samples were re-installed in the same layers of the soil profile from which the samples had been taken. Three replicates were used for each layer. Gas samples were taken every $24 \mathrm{~h}$ out of the jars headspace with a gastight syringe. $\mathrm{CH}_{4}$ production rates were calculated from the linear increase in $\mathrm{CH}_{4}$ concentration analysed by gas chromatography.

The $\mathrm{CH}_{4}$ oxidation capacity was studied considering the in situ $\mathrm{CH}_{4}$ concentration and the natural soil temperature gradient. Fresh soil material ( $5 \mathrm{~g}$, well homogenized) from different soil horizons was weighed into $50-\mathrm{ml}$ glass jars and closed with a screw cap with septum. All samples were supplied with about $2000 \mathrm{ppm}^{\mathrm{CH}_{4}}$ (corresponding to about $800 \mu \mathrm{mol} \mathrm{CH}_{4} \mathrm{1}^{-1}$ pore water). The samples were treated in the same way as described for measurement of methane formation, with the exception that gas samples were taken every $12 \mathrm{~h}$. $\mathrm{CH}_{4}$ oxidation capacities were calculated from the linear decrease in $\mathrm{CH}_{4}$ concentration analysed by gas chromatography.

\section{Calculation}

In order to calculate the balance between both microbial processes and to compare these data with the measured $\mathrm{CH}_{4}$ fluxes $\left(\mathrm{F}_{\mathrm{act}}\right)$, the potential $\mathrm{CH}_{4}$ fluxes $\left(\mathrm{F}_{\text {pot }}\right)$ were determined from the $\mathrm{CH}_{4}$ production and oxidation rates according to the following equation:

$$
F_{p o t}=M_{C H_{4}} \sum_{i=1}^{n}\left(x_{p i}-x_{o i}\right) * B D_{i} * y_{i}
$$

$F_{\text {pot }}$ potential $\mathrm{CH}_{4}$ flux from soils into the atmosphere $\left[\mathrm{mg} \mathrm{m}^{-2} \mathrm{~d}^{-1}\right]$

$n \quad$ number of horizons in the soil profile

$x_{p i} \quad \mathrm{CH}_{4}$ production rate in horizon $i\left[\mathrm{mmol} \mathrm{g}^{-1}\right.$ $\mathrm{d}^{-1}$ ]

$x_{o i} \quad \mathrm{CH}_{4}$ oxidation rate in horizon $i\left[\mathrm{mmol} \mathrm{g}^{-1}\right.$ $\left.\mathrm{d}^{-1}\right]$

$M_{\mathrm{CH}_{4}}$ molar mass of $\mathrm{CH}_{4}\left[\mathrm{~g} \mathrm{~mol}^{-1}\right]$

$B D_{i} \quad$ bulk density of horizon $i\left[\mathrm{~g} \mathrm{~m}^{-3}\right]$

$y_{i} \quad$ thickness of horizon $i[\mathrm{~m}]$ 


\section{Environmental Conditions}

Daily soil temperature, water table and thaw depth were determined manually at the same time as $\mathrm{CH}_{4}$ flux samples were taken. The soil temperature was measured at $5-\mathrm{cm}$ increments from 0 to $15 \mathrm{~cm}$ depth at the polygon rim and depression. Additional temperature measurements were carried out during the experiments of in situ $\mathrm{CH}_{4}$ production and oxidation $(5-\mathrm{cm}$ increments from 0 to $40 \mathrm{~cm}$ soil depth). The water table position relative to the soil surface was measured in a series of slotted wells distributed over the polygon. The thaw depth was determined by inserting a steel rod into the soil until permafrost was encountered. The $\mathrm{pH}$ of the soil pore water was measured after sampling the soil solution from different depths by suction lysimeters.

\section{Carbon Analysis}

Dissolved organic carbon (DOC) was extracted in July and in August, respectively, from soil samples of two vertical profiles (polygon depression and rim). Fresh soil material $(9 \mathrm{~g})$ was taken at $5-\mathrm{cm}$ intervals down to a depth of $30 \mathrm{~cm}$ in the polygon depression and to a depth of $40 \mathrm{~cm}$ in the polygon rim. The samples from each layer were weighed into glass jars $(50 \mathrm{ml})$ and mixed with $45 \mathrm{ml}$ distilled water. The bottles were closed and shaken for $1 \mathrm{~h}$ in the dark. Afterwards the suspension was filtered (mesh $0.45 \mu \mathrm{m}$, Gelman Science) and the clear solution was inactivated by adding sodium azide. The DOC analysis was done with an Elementar High-TOC-II.

Total organic carbon (TOC) was analysed with an element analysator (Elementar Vario EL) using dried and homogenized soil samples. Prior to analysis the samples were treated with $\mathrm{HCl}(10 \%)$ at $80^{\circ} \mathrm{C}$ for carbonate removal.

\section{Gas Analysis}

$\mathrm{CH}_{4}$ concentrations were determined with a gas chromatograph (Chrompack GC 9003) in the field laboratory. The instrument was equipped with a Poraplot Q (100/120 mesh, $20 \mathrm{ft})$ capillary column, which operated with pure helium as carrier gas at a flow rate of $20 \mathrm{ml} \mathrm{min}-1$. $\mathrm{CH}_{4}$ was analysed by a flame ionization detector. The injector/detector temperatures were set at $160^{\circ} \mathrm{C}$ and the column oven at $80^{\circ} \mathrm{C}$. All gas sample analyses were done after calibration of the gas chromatograph with standard gases.

\section{RESULTS}

\section{$\mathrm{CH}_{4}$ Fluxes}

The $\mathrm{CH}_{4}$ fluxes of the depression differed strongly from those of the rim of a wet polygon tundra. The mean flux rate for the total vegetation period (June-September) of the depression was $53.2 \pm$ $8.7 \mathrm{mg} \mathrm{CH}_{4} \mathrm{~m}^{-2} \mathrm{~d}^{-1}$, whereas the mean flux rate of the dryer rim part of the polygon was $4.7 \pm 2.5$ $\mathrm{CH}_{4} \mathrm{~m}^{-2} \mathrm{~d}^{-1}$. The emission of $\mathrm{CH}_{4}$ from the depression covered dominantly by Carex aquatilis showed large seasonal fluctuations. Right from the start of soil thawing a relatively high $\mathrm{CH}_{4}$ flux rate of more than $10 \mathrm{mg} \mathrm{CH}_{4} \mathrm{~m}^{-2} \mathrm{~d}^{-1}$ was determined at the beginning of June (Figure 3a). This rate increased with advanced thawing of the active layer and reached the highest values with $100-120 \mathrm{mg} \mathrm{CH}_{4} \mathrm{~m}^{-2} \mathrm{~d}^{-1}$ in the middle of July. During the second half of July, $\mathrm{CH}_{4}$ fluxes decreased continuously and attained a constant rate of about $25 \mathrm{mg} \mathrm{CH}_{4} \mathrm{~m}^{-2} \mathrm{~d}^{-1}$ in August, when the maximum thawing depth of the active layer was reached (Figure $3 b$ ). During the early vegetation period from the end of May to mid-July (99-0525 to 99-07-15) the $\mathrm{CH}_{4}$ fluxes were significantly correlated $(r=0.937)$ with the thawing of the active layer (Figure 4), whereas no correlation was observed between $\mathrm{CH}_{4}$ fluxes and soil temperature (data not shown). In contrast to the polygon depression, $\mathrm{CH}_{4}$ fluxes of the rim, which is dominated by a moss vegetation, showed no seasonal fluctuation. During the whole season the rate was lower than $10 \mathrm{mg}$ $\mathrm{CH}_{4} \mathrm{~m}^{-2} \mathrm{~d}^{-1}$.

$\mathrm{CH}_{4}$ concentration of the pore water within the soils of both the rim and the depression of the polygon increased with depth. The concentrations for both soils were in the same order of magnitude. It varied between 0.1 and $489.3 \mu \mathrm{mol} \mathrm{CH}_{4} \mathrm{I}^{-1}$ soil solution within the Typic Historthel and between 0.9 and $766.5 \mu \mathrm{mol} \mathrm{CH}_{4} \mathrm{1}^{-1}$ soil solution within the Glacic Aquiturbel, respectively (Table 1).

\section{Microbial $\mathrm{CH}_{4}$ Production and Oxidation}

The in situ $\mathrm{CH}_{4}$ production of the Typic Historthel (polygon depression) showed significant differences in the upper soil layer $(0-5 \mathrm{~cm}$ depth) measured in July and August (Figure 5a, 5b). At the beginning of August the $\mathrm{CH}_{4}$ production was about 10 times lower $\left(4.7 \pm 1.3 \mathrm{nmol} \mathrm{CH}_{4} \mathrm{~h}^{-1} \mathrm{~g}^{-1}\right.$, Figure $\left.5 \mathrm{~b}\right)$ than the rate at the beginning of July, which was $38.9 \pm$ $2.9 \mathrm{nmol} \mathrm{CH}_{4} \mathrm{~h}^{-1} \mathrm{~g}^{-1}$ (Figure 5a). With increasing soil depth, $\mathrm{CH}_{4}$ production rate decreased at both 


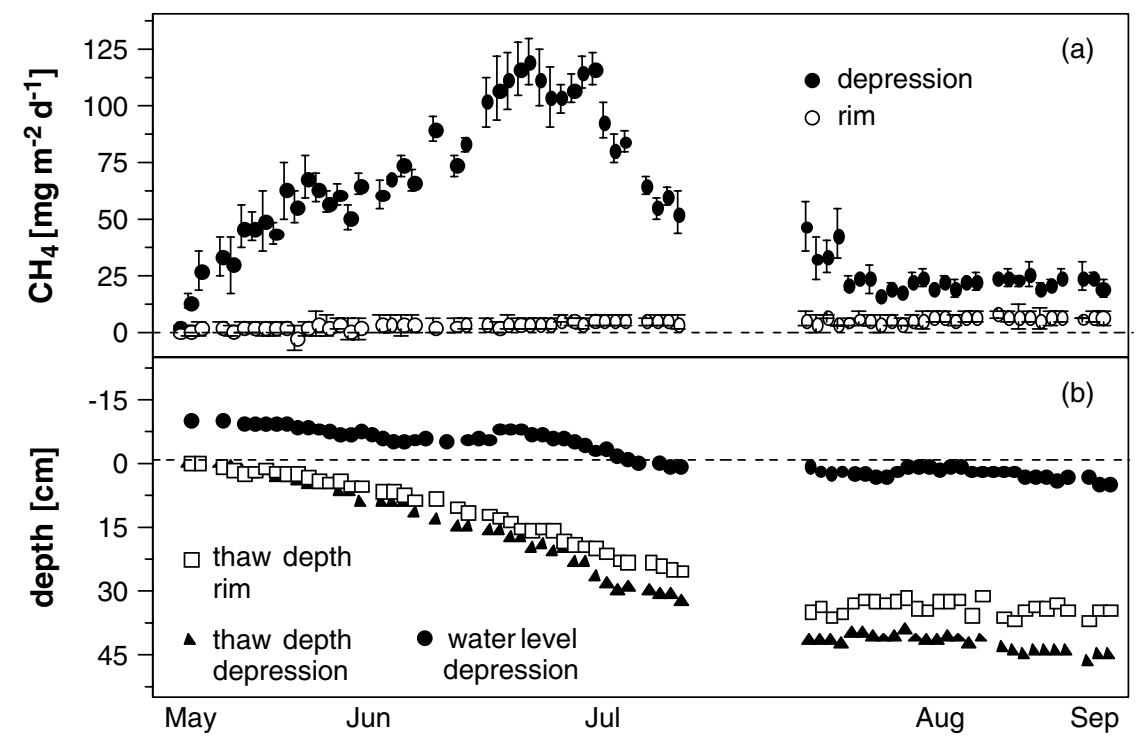

Figure $3 \mathrm{CH}_{4}$ flux and environmental variables of a low-centered polygon measured from the beginning of June to the beginning of September 1999. (a) $\mathrm{CH}_{4}$ emission from the polygon depression and rim; mean $\pm \mathrm{SE}, \mathrm{n}=5$; (b) water level of the polygon depression and thaw depth of the polygon depression and rim.

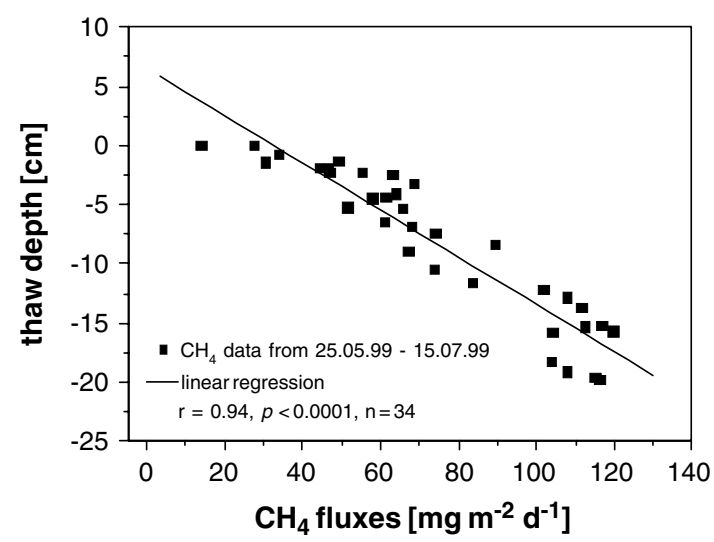

Figure 4 Relationship of $\mathrm{CH}_{4}$ fluxes to the thaw depth of the active layer for the period 25 May to 15 July 1999.

measuring times. In contrast to the top soil, the production rates for the deeper soil layers were in the same order of magnitude (approximately between 1-4 nmol $\mathrm{CH}_{4} \mathrm{~h}^{-1} \mathrm{~g}^{-1}$ ). The natural soil temperature gradient decreased from the top to the bottom of the soil. The temperature varied between 9.4 and $0.9^{\circ} \mathrm{C}$ in July and was slightly lower in August with $7.5-0.4^{\circ} \mathrm{C}$.

Compared to the in situ $\mathrm{CH}_{4}$ production, the $\mathrm{CH}_{4}$ oxidation capacity of the studied soil was completely different. At the beginning of July, $\mathrm{CH}_{4}$ oxidation was only observed in the upper soil layer with a rate of $1.9 \pm 0.3 \mathrm{nmol} \mathrm{CH}_{4} \mathrm{~h}^{-1} \mathrm{~g}^{-1}$, while no $\mathrm{CH}_{4}$ oxidation was detectable in the deeper soil layers (Figure 6a). In August $\mathrm{CH}_{4}$ oxidation was registered through the entire vertical profile with the exception of the bottom layer (Figure 6b). The rates varied between $4.1 \pm 0.3$ and $7.0 \pm 1.3 \mathrm{nmol} \mathrm{CH}_{4} \mathrm{~h}^{-1} \mathrm{~g}^{-1}$, but in contrast to the $\mathrm{CH}_{4}$ production the $\mathrm{CH}_{4}$ oxidation did not decrease with the soil depth.

The potential $\mathrm{CH}_{4}$ flux $\left(F_{\text {pot }}\right)$ from the polygon depression calculated from the $\mathrm{CH}_{4}$ production (119.1 $\left.\mathrm{mg} \mathrm{CH}_{4} \mathrm{~m}^{-2} \mathrm{~d}^{-1}\right)$ and oxidation rates $(5.0 \mathrm{mg}$ $\mathrm{CH}_{4} \mathrm{~m}^{-2} \mathrm{~d}^{-1}$ ) was in the same order of magnitude (114.1 $\mathrm{mg} \mathrm{CH}_{4} \mathrm{~m}^{-2} \mathrm{~d}^{-1}$ ) compared to the measured $\mathrm{CH}_{4}$ fluxes (approximately $110 \mathrm{mg} \mathrm{CH}_{4} \mathrm{~m}^{-2} \mathrm{~d}^{-1}$ ) at the beginning of July. The calculated balance of $\mathrm{CH}_{4}$ production and oxidation at the beginning of August revealed a negative flux rate $(28.7-66.4=$ $-37.7 \mathrm{mg} \mathrm{CH}_{4} \mathrm{~m}^{-2} \mathrm{~d}^{-1}$ ), suggesting a higher oxidation rate than the production rate.

The $\mathrm{CH}_{4}$ production and oxidation activity of the Glacic Aquiturbel (polygon rim) was lower and showed another distribution within the profile compared to the Typic Historthel. The $\mathrm{CH}_{4}$ production ranged from $0.2 \pm 0.09$ to $1.0 \pm 0.2 \mathrm{nmol}$ $\mathrm{CH}_{4} \mathrm{~h}^{-1} \mathrm{~g}^{-1}$ (Figure 7). No $\mathrm{CH}_{4}$ production was found in the upper soil layers between 0 and $20 \mathrm{~cm}$ depth, while the highest $\mathrm{CH}_{4}$ production was detected 
Table 1 Selected soil properties of the study sites.

\begin{tabular}{|c|c|c|c|c|c|c|}
\hline Horizon* & Depth $[\mathrm{cm}]$ & $\mathrm{CH}_{4}$ concentration $\left[\mu \mathrm{mol} \mathrm{l}^{-1}\right]$ & TOC $[\%]$ & $\mathrm{DOC}^{\dagger}[\mathrm{mg} \mathrm{1-1}]$ & $\mathrm{DOC}^{\ddagger}[\mathrm{mg} \mathrm{l-1}]$ & $\mathrm{pH}$ \\
\hline \multicolumn{7}{|c|}{ Polygon depression (Typic Historthel) } \\
\hline Oil & $0-5$ & 0.1 & 18.4 & 17.4 & 11.7 & n.d. \\
\hline Oi2 & $5-10$ & 6.4 & 14.0 & 13.6 & 8.8 & 7.9 \\
\hline $\mathrm{Ajj}$ & $10-17$ & 15.8 & 13.8 & 25.2 & 4.7 & 7.4 \\
\hline $\mathrm{Bg} 1$ & $17-23$ & 39.9 & 8.1 & 12.0 & 9.5 & n.d. \\
\hline Bg2 & $23-30$ & 116.9 & 4.6 & 9.3 & 11.9 & n.d. \\
\hline Bg2 & $30-35$ & 280.5 & 3.6 & 7.2 & 12.8 & n.d. \\
\hline Bg3 & $35-40$ & 489.3 & 4.3 & 10.5 & n.d. & n.d. \\
\hline \multicolumn{7}{|c|}{ Polygon rim (Glacic Aquiturbel) } \\
\hline $\mathrm{Ajj}$ & $0-5$ & 0.9 & 2.1 & 7.3 & 7.3 & n.d. \\
\hline Bjjg1 & $5-12$ & 0.7 & 2.0 & 7.1 & 6.8 & n.d. \\
\hline Bjjg2 & $12-20$ & 98.2 & 2.4 & 9.0 & 4.0 & 7.9 \\
\hline Bjjg2 & $20-27$ & 158.3 & 3.0 & 7.3 & 5.4 & 6.7 \\
\hline Bjjg2 & $27-35$ & 441.6 & 2.4 & 4.0 & 6.4 & 6.8 \\
\hline Bjjg3 & $35-42$ & 395.9 & 2.7 & 8.7 & 8.3 & n.d. \\
\hline Bjjg3 & $42-49$ & 766.5 & 3.3 & 17.3 & 10.6 & n.d. \\
\hline
\end{tabular}

* Horizon nomenclature and ${ }^{\S}$ soil classification according to Soil Survey Staff (1998). ${ }^{\dagger}$ First extraction of DOC at the beginning of July. ${ }^{\ddagger}$ Second extraction of DOC at the beginning of August 1999 . TOC = total organic carbon; $\mathrm{DOC}=$ dissolved organic carbon; n.d. $=$ not detected.

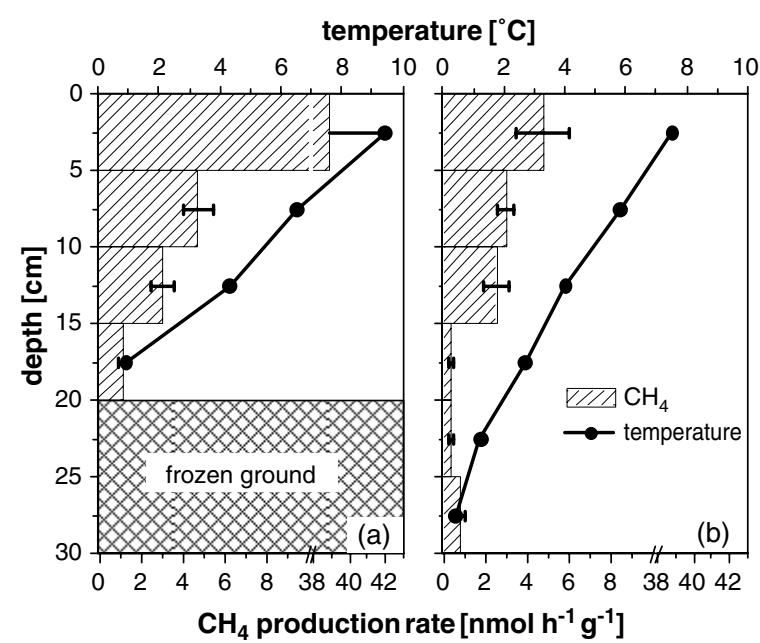

Figure 5 Vertical profile of $\mathrm{CH}_{4}$ production and in situ soil temperature, polygon depression. $\mathrm{CH}_{4}$ production rate and soil temperature determined at (a) the beginning of July 1999 and (b) the beginning of August 1999 .

in the boundary to the frozen ground. The $\mathrm{CH}_{4}$ oxidation capacity varied between $0.2 \pm 0.05$ and $0.9 \pm 0.1 \mathrm{nmol} \mathrm{CH}_{4} \mathrm{~h}^{-1} \mathrm{~g}^{-1}$ (Figure 7). The highest oxidation rates were observed in the bottom layers, where significant in situ $\mathrm{CH}_{4}$ production prevails. The soil temperature decreased with the soil depth from 6.4 to $1.0^{\circ} \mathrm{C}$.

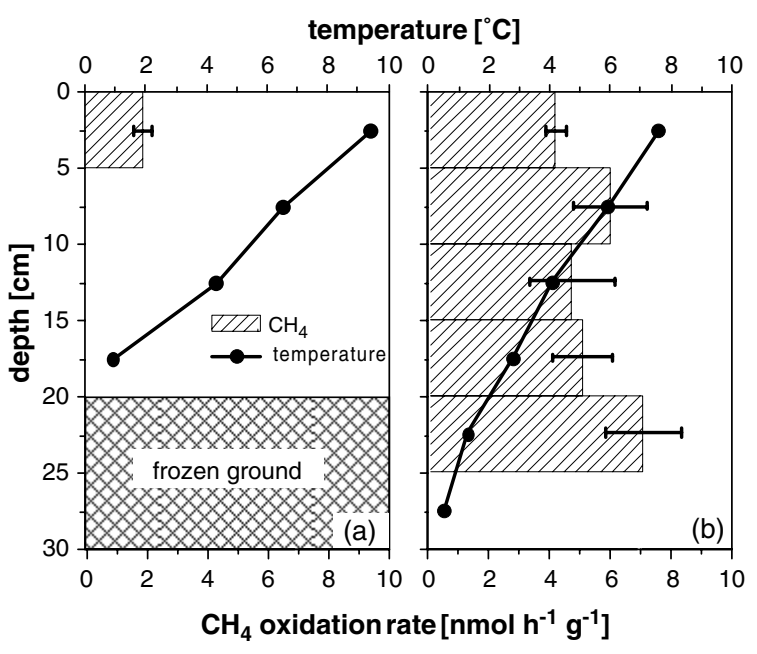

Figure 6 Vertical profile of $\mathrm{CH}_{4}$ oxidation capacity and in situ soil temperature, polygon depression. $\mathrm{CH}_{4}$ oxidation rate and soil temperature determined at (a) the beginning of July 1999 and (b) the beginning of August 1999 (b).

\section{Soil Characteristics}

In the upper $15 \mathrm{~cm}$, average soil temperature in the polygon depression (Typic Historthel) systematically was about $3{ }^{\circ} \mathrm{C}$ higher than in the comparable depths of the polygon rim (Glacic Aquiturbel, Figure 8). While the upper soil temperature exhibited highly 


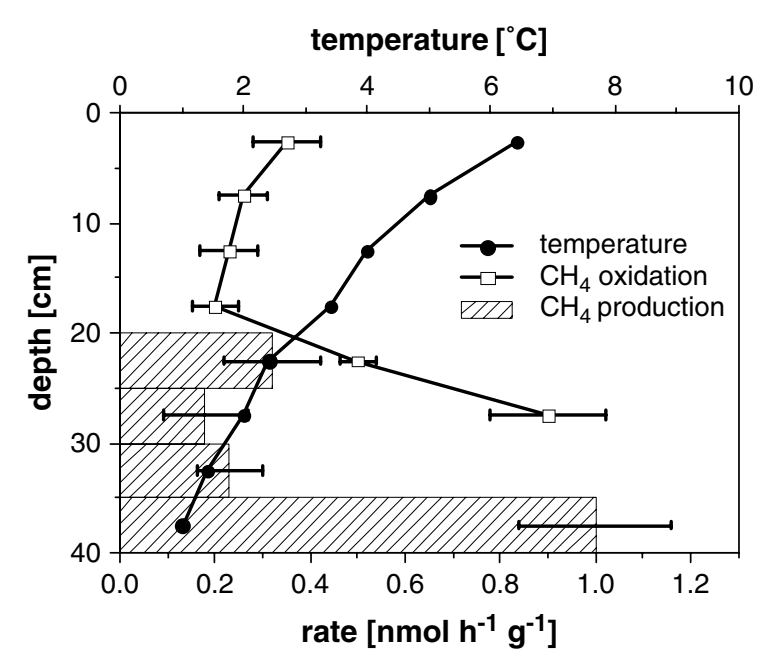

Figure 7 Vertical profile of $\mathrm{CH}_{4}$ production and $\mathrm{CH}_{4}$ oxidation capacity and in situ soil temperature within the polygon rim determined in August 2000.

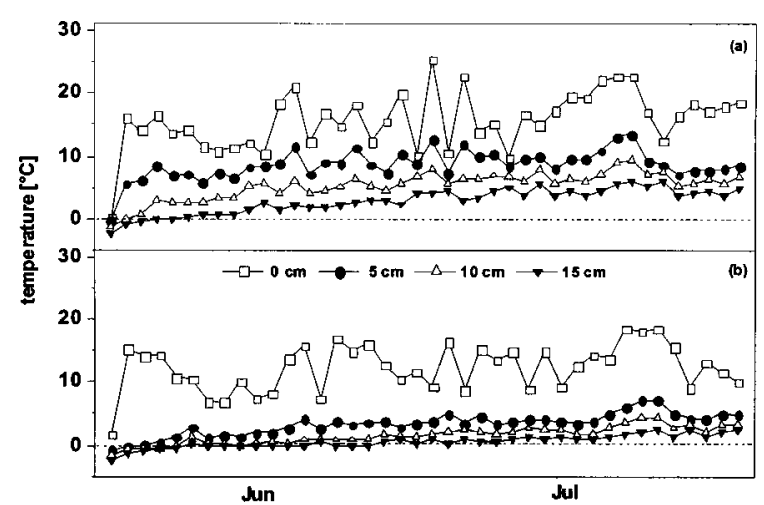

Figure 8 Soil temperature of a low-centred polygon measured in June and July 1999 at the $\mathrm{CH}_{4}$ flux site: (a) depression; (b) rim.

diurnal fluctuations, the deeper soil layers showed a relatively constant temperature around $1.8^{\circ} \mathrm{C}$ for the rim and $5.7^{\circ} \mathrm{C}$ for the depression, which slightly increased to 3.6 and $6.8^{\circ} \mathrm{C}$, respectively, over the season.

The water level relative to the soil surface of the polygon depression decreased during the season. From the beginning of June to mid-July the polygon depression was water-filled. Afterwards the water level fell slowly under the soil surface and reached the lowest extent in August (Figure 3b). The maximum thaw depth of the soils was reached in August, with $35 \mathrm{~cm}$ in the polygon depression and $45 \mathrm{~cm}$ in the polygon rim (Figure $3 \mathrm{~b}$ ). The $\mathrm{pH}$ values measured in the soil pore water during the field campaign ranged from $\mathrm{pH} 6.7$ to 7.9 (Table 1).

The organic carbon (TOC) contents showed a large variability within the micro-relief (Table 1). The Typic Historthel of the polygon depression was characterized by a high amount of TOC, which ranged from 18.4 to $3.6 \%$ and decreased within the vertical profile of the soil. Contrary, the TOC content of the Glacic Aquiturbel was much lower (2.0-3.3\%) and of small variability. Because of the different carbon pools of both soils, the average amount of DOC in the Typic Historthel was $13.6 \mathrm{mg}^{-1}$ in July and $9.9 \mathrm{mg}^{-1}$ in August, while the average amount of DOC in the Glacic Aquiturbel was $8.7 \mathrm{mg}^{-1}$ in July and $6.9 \mathrm{mg}^{-1}$ in August (Table 1). The DOC concentrations were remarkable higher in the upper soil layers of the polygon depression in July compared to the concentrations in August, while the DOC values of the polygon rim were similar in both months. A distinct tendency of DOC distribution could not be recognized in the vertical profile of the soils.

\section{DISCUSSION}

The $\mathrm{CH}_{4}$ emission rates are from a tundra environment of the Lena Delta, northeastern Siberia, and were measured during the expedition Lena 1999 for a period of $14 \mathrm{wk}$ from the beginning to the end of the vegetation period. The $\mathrm{CH}_{4}$ flux data were obtained within the scope of a long-term study of trace gas emissions carried out since 1998 . The results revealed considerable variations of $\mathrm{CH}_{4}$ emissions from the polygon depression during the vegetation period, while during the same time the polygon rim showed a relatively constant emission rate. The highest fluxes occurred in mid-July, the lowest in early spring as well as in autumn.

Although long-term studies of methane emission rates are necessary for the refinement of global $\mathrm{CH}_{4}$ flux estimates (Matthews and Fung, 1987), few studies on $\mathrm{CH}_{4}$ fluxes in the high arctic consider a measuring period of more than $4 \mathrm{wk}$ (Bartlett et al., 1992; Whalen and Reeburgh, 1992; Vourlitis et al., 1993; Christensen et al., 2000; Nakano et al., 2000; Tsuyuzaki et al, 2001). Most calculations are based on measurements made of a couple of days for the whole season (e.g. Torn and Chapin, 1993; Christensen et al., 1995; Oberbauer et al, 1998; Verville et al., 1998). Investigations of $\mathrm{CH}_{4}$ fluxes in the Russian Arctic over several years have not been published yet. However, the former studies (see above) yielded results that suggest 
pronounced seasonal variations in $\mathrm{CH}_{4}$ release, which were attributed to environmental variables like temperature and soil moisture. The essential $\mathrm{CH}_{4}$ production and oxidation rates caused by the underlying microbiological processes in permafrost soils have been measured only in few studies under in situ conditions (Vecherskaya et al., 1993; Samarkin et al., 1999). Therefore the microbial activities are not well understood within the context of $\mathrm{CH}_{4}$ flux analyses.

In this study, the microbiological processes of the polygon depression could be clearly correlated with the observed seasonal $\mathrm{CH}_{4}$ fluctuations. At the beginning of July, the $\mathrm{CH}_{4}$ production in the upper soil layer was unusually high with a rate of about $39 \mathrm{nmol} \mathrm{CH}_{4} \mathrm{~h}^{-1} \mathrm{~g}^{-1}$. At the same time, $\mathrm{CH}_{4}$ oxidation in the upper soil layer amounted to about $2 \mathrm{nmol} \mathrm{CH}_{4} \mathrm{~h}^{-1} \mathrm{~g}^{-1}$, whereas no activity was found in the deeper soil layers. Considering the analysed $\mathrm{CH}_{4}$ production and oxidation rates and the calculated potential fluxes within the soil profile, only $4 \%$ of the produced methane is oxidized by the methanotrophic bacteria in the upper soil layer. Compared with other ecosystems, where up to $90 \%$ of the formed $\mathrm{CH}_{4}$ can be oxidized by methanotrophic bacteria (Frenzel et al., 1990; Khalil et al., 1998), their oxidation activity in the permafrost soil is very low at the beginning of the vegetation period. The high $\mathrm{CH}_{4}$ production rate together with the low $\mathrm{CH}_{4}$ oxidation rate explain the highest $\mathrm{CH}_{4}$ fluxes determined in July 1999.

At the beginning of August, the $\mathrm{CH}_{4}$ production and oxidation activity of the microorganisms differed completely from the July rates. The $\mathrm{CH}_{4}$ production in the upper soil layer drastically decreased to about $4.5 \mathrm{nmol} \mathrm{CH}_{4} \mathrm{~h}^{-1} \mathrm{~g}^{-1}$, while the $\mathrm{CH}_{4}$ oxidation, which could be detected now in nearly the whole profile, strongly increased to rates between 4 and $7 \mathrm{nmol} \mathrm{CH}_{4} \mathrm{~h}^{-1} \mathrm{~g}^{-1}$. The calculated balance of the $\mathrm{CH}_{4}$ production and oxidation for the whole profile showed that the microbial $\mathrm{CH}_{4}$ oxidation capacity $\left(66 \mathrm{mg} \mathrm{m}^{-2} \mathrm{~d}^{-1}\right)$ in this period was about twice as high as the microbial $\mathrm{CH}_{4}$ production $\left(29 \mathrm{mg} \mathrm{m}^{-2}\right.$ $\left.\mathrm{d}^{-1}\right)$. Nevertheless, a significant $\mathrm{CH}_{4}$ release from the polygon depression was also determined in August 1999, which can be attributed to the influence of the vegetation. It is well known that a substantial part of formed $\mathrm{CH}_{4}$ is transported through the aerenchyma of vascular plants into the atmosphere (Whiting and Chanton, 1992; Morrissey et al., 1993; Tsuyuzaki et al. 2001). L. Kutzbach (personal communication, 2003) demonstrated at the same investigation site a $\mathrm{CH}_{4}$ transport through the dominating sedge Carex aquatilis, accounting for about $68 \%$ of the total $\mathrm{CH}_{4}$ emission rates. Thus, the microbial oxidation of $\mathrm{CH}_{4}$ in the aerobic soil zones is bypassed. Consequently, also at the shown ratio of $\mathrm{CH}_{4}$ production and $\mathrm{CH}_{4}$ oxidation, a significant $\mathrm{CH}_{4}$ release had taken place.

The $\mathrm{CH}_{4}$ fluxes and the microbial activities at the polygon rim were much lower than those appearing in the polygon depression. Our results underlined the influence of the micro-relief on $\mathrm{CH}_{4}$ fluxes, as also described for a polygonal tundra setting on Taimyr Peninsula (Samarkin et al., 1999). Thus, the top soil of the rim was much dryer than the depression with a distinct redox gradient. Therefore, $\mathrm{CH}_{4}$ production was only found in the anaerobic bottom layer of the rim. Since the $\mathrm{CH}_{4}$ oxidation was in the same range as the $\mathrm{CH}_{4}$ production, and the plant-mediated $\mathrm{CH}_{4}$ transport could be neglected at this site, the $\mathrm{CH}_{4}$ emission rate at the rim of the polygon was low.

The seasonal changes of microbial activities are based on different environmental parameters. With the beginning of the vegetation season, a strong relationship between $\mathrm{CH}_{4}$ fluxes and the thawing of the soil was deduced for the depression, whereas no correlation between $\mathrm{CH}_{4}$ fluxes and the soil temperature was found over the whole season (data not shown). These results are in contrast to other investigations carried out by a number of authors (Morrissey and Livingston, 1992; Christensen et al., 1995; Hargreaves and Fowler, 1998; Verville et al., 1998), who found a strong relationship between the $\mathrm{CH}_{4}$ emission and the air or soil temperature, respectively. Our investigations of the methanogenic activity under in situ conditions showed a substantial $\mathrm{CH}_{4}$ production in the lower boundary of the active layer, which was characterized by a temperature of about $1{ }^{\circ} \mathrm{C}$. Just as $\mathrm{CH}_{4}$, oxidation by methanotrophic bacteria is independent from the temperature gradient of the soil. We assume that the microorganisms are well adapted to the extreme temperature regime of permafrost soils. Otherwise they would not have shown any activity at such low temperatures (Morita, 1992). This assumption was confirmed by the work of Omelchenko et al. (1993), who described a cold-adapted (psychrophilic) methane-oxidizing microbial community from Siberian tundra soils. Franzmann et al. (1997) described the only known strain of a psychrophilic methanogenic archaea isolated from Ace Lake, Antarctica. However, the in situ analyses showed that methanogenesis and methane consumption occurred with a high rate even at extremely low temperatures, whereby the temperature had only a subordinate relevance for the $\mathrm{CH}_{4}$ fluxes of the investigated permafrost soils. 
Furthermore, the adapted methanogenic archaeal community likely produced methane continuously during the back freezing of the soil in autumn. Apparently, this methane might be entrapped into the active layer and can be released in the thawing period of the following spring. Samarkin et al. (1999) already assumed that such back-stored methane adds to the emission of newly-produced methane. This process is evidenced by our results showing the coincidence of enhanced $\mathrm{CH}_{4}$ fluxes and the onset of soil thawing in spring and early summer (Figure 4).

Further important factors affecting microbiological processes are the water table and the available substrate. The results revealed a high methane release in June/July, when water level is high and a low methane release at low water level in August/September (Figure 3). The measured $\mathrm{CH}_{4}$ oxidation showed that the activity of the oxygendependent methanotrophic bacteria clearly increased with sinking water levels, because more oxygen was available for the oxidation process. The activity of the anaerobic methanogenic archaea in the permafrost soil was less affected by a falling water level, although methanogens are regarded as strictly anaerobic organisms. $\mathrm{CH}_{4}$ production occurred in wetland soils in the presence of oxygen, because methanogenic bacteria are well protected against oxygen by the activity of indigenous facultative anaerobic microflora (Wagner et al., 1999).

In contrast to methanotrophic bacteria, which use methane as the only source of energy and carbon, the activity of methanogenic archaea mainly depends on the quality and quantity of available organic matter (Bergman et al., 2000). The latter relationship is confirmed by our results, as the highest $\mathrm{CH}_{4}$ production was determined in the upper soil horizons, in accordance with the highest measured TOC content. However, DOC concentrations were lower in these horizons in August than in July. Accordingly, the activity of methanogenic archaea decreased from July to August in the upper soil layers. Thus, the $\mathrm{CH}_{4}$ production seems to be primarily controlled by the available substrate. This result is supported by the investigations of Bianchi et al. (1996), who reported that the $\mathrm{CH}_{4}$ production in a river floodplain depends mainly on the quality and quantity of DOC.

\section{CONCLUSION}

Our results demonstrate the close relationship between $\mathrm{CH}_{4}$ fluxes and the fundamental microbiological processes of $\mathrm{CH}_{4}$ production and oxidation in polygonal tundra soils. An important finding is that in addition to the soil characteristics and the climate

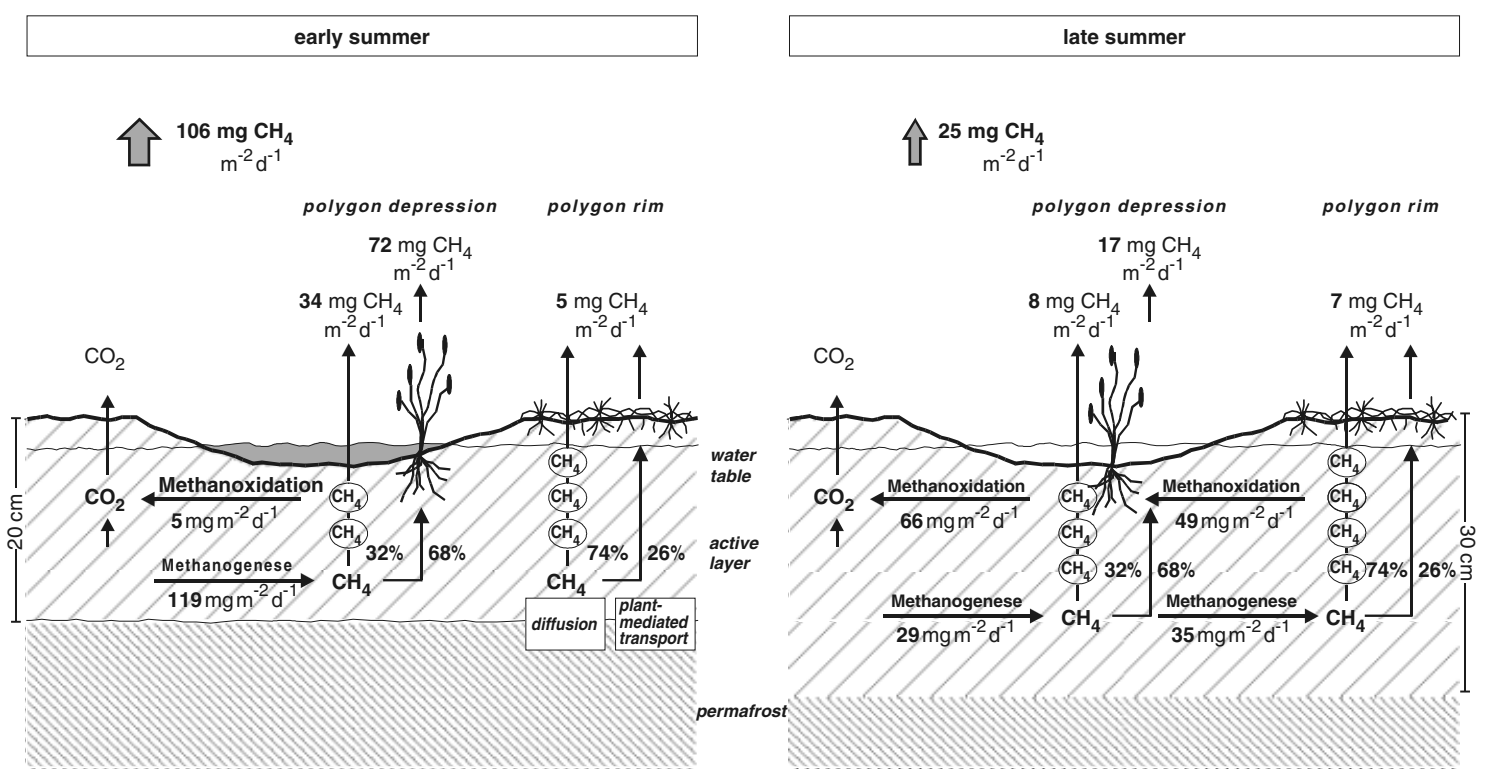

Figure 9 Illustration of the microbial processes associated with the methane cycle as well as the methane flux rates of a polygonal tundra on the basis of the spring and late summer conditions (explanations are given in the Discussion). The results of plant-mediated methane transport are included from L Kutzbach (personal communication, 2003). 
conditions, a knowledge of the activity, physiology, and ecology of the bacteria community is fundamental for understanding trace gas fluxes in permafrost soils as compiled in Figure 9 for this case study. Such a sophisticated view of the small-scale microbiological processes in cold soils and the associated modes of methane release is needed also for other key locations in the Arctic. In outlook, this approach provides the basis for future environmental studies that deal with the fate of carbon stored in permafrost soils in the course of climate change.

\section{ACKNOWLEDGEMENTS}

The authors wish to thank the Russian-German field parties during the expedition Lena 1999. Special thanks go to Dmitri Melnitschenko (Hydro Base Tiksi) and Waldemar Schneider (Alfred-WegenerInstitut für Polar- und Meeresforschung) for logistic support during the expedition. In addition, we thank Dr E. Spieck (Universität Hamburg, Institut für Allgemeine Botanik, Abteilung Mikrobiologie) and Dr B. Diekmann (Alfred-Wegener-Institut für Polarund Meeresforschung) for critical reading of the manuscript. The study is part of the German-Russian project The Laptev Sea System (03G0534G), which was funded by the German Ministry of Education and Research (BMBF) and the Russian Ministry of Research and Technology.

\section{REFERENCES}

Are F, Reimnitz E. 2000. An overview of the Lena River Delta settings: geology, tectonics, geomorphology, and hydrology. Journal of Coastal Research 16: 1083-1093. Aselman I, Crutzen J. 1989. Global distribution of natural freshwater wetlands and rice paddies, their net primary productivity, seasonality and possible methane emissions. Journal of Atmospheric Chemistry 8: $307-358$.

Bartlett KB, Crill PM, Sass RL, Harriss RC, Dise NB. 1992. Methane emissions from tundra environments in the Yukon-Kuskokwim Delta, Alaska. Journal of Geophysical Research 97: 16645-16660.

Bergman I, Klarqvist M, Nilsson M. 2000. Seasonal variation in rates of methane production from peat of various botanical origins: effects of temperature and substrate quality. FEMS Microbiology Ecology 33 : 181-189.

Bianchi TS, Freer ME, Wetzel RG. 1996. Temporal and spatial variability, and the role of dissolved organic carbon (DOC) in methane fluxes from the Sabine River Floodplain (Southeast Texas, U.S.A.). Archiv für Hydrobiologie 136: 261-287.
Bubier JA, Moore TR, Bellisario L, Comer NT. 1995. Ecological controls on methane emissions from a northern peatland complex in the zone of discontinuous permafrost, Manitoba, Canada. Global Biogeochemical Cycles 9: 455-470.

Christensen TR, Jonasson S, Callaghan TV, Havström M. 1995. Spatial variation in high-latitude methane flux along a transect across Siberian and European tundra environments. Journal of Geophysical Research 100: 21035-21045.

Christensen TR, Prentice IC, Kaplan J, Haxeltine A, Sitch S. 1996. Methane flux from northern wetlands and tundra: an ecosystem source modelling approach. Tellus 48B: 651-660.

Christensen TR, Friborg T, Sommerkorn M, Kaplan J, Illeris L, Soegaard H, Nordstroem C, Jonasson S. 2000. Trace gas exchange in a high-arctic valley: 1 . variations in $\mathrm{CO}_{2}$ and $\mathrm{CH}_{4}$ flux between tundra vegetation types. Global Biogeochemical Cycle 14: 701-713.

Deppenmeier U, Müller V, Gottschalk G. 1996. Pathways of energy conservation in methanogenic archaea. Archive of Microbiology 165: 149-163.

Ehhalt DH, Schmidt U. 1978. Sources and sinks of atmospheric methane. Pure and Applied Geophysics 116: $452-464$.

Franzmann PD, Liu Y, Balkwill DL, Aldrich HC, Conway de Macario E, Boone DR. 1997. Methanogenium frigidium sp. nov., a psychrophilic $\mathrm{H}_{2}$-using methanogen from Ace Lake, Antarctica. International Journal of Systematic Bacteriology 47: 1068-1072.

Frenzel P, Karofeld E. 2000. $\mathrm{CH}_{4}$ emission from a hollowridge complex in a raised bog: the role of $\mathrm{CH}_{4}$ production and oxidation. Biogeochemistry 51: 91-112.

Frenzel P, Thebrath B, Conrad R. 1990. Oxidation of methane in the oxic surface layer of a deep lake sediment (Lake Constance). FEMS Microbiology Ecology 73: $149-158$.

Fung I, John J, Lerner J, Matthews E, Prather M, Steele LP, Fraser PJ. 1991. Three-dimensional model synthesis of the global methane cycle. Journal of Geophysical Research 96D: 13 033-13065.

Garcia J-L, Patel BKC, Ollivier B. 2000. Taxonomic, phylogenetic, and ecological diversity of methanogenic Archaea. Anaerobe 6: 205-226.

Hansen J, Fung I, Lacis A, Rind D, Lebedeff S, Ruedy R, Russell G, Stone P. 1988. Global climate changes as forecast by Goddard Institute for Space Studies threedimensional model. Journal of Geophysical Research 93: 9341-9364.

Hanson RS, Hanson TE. 1996. Methanotrophic bacteria. Microbiological Reviews 60: 439-471.

Hargreaves KJ, Fowler D. 1998. Quantifying the effects of water table and soil temperature on the emission of methane from peat wetland at the field scale. Atmospheric Environment 32: 3275-3282.

Joabsson A, Christensen TR, Wallen B. 1999. Vascular plant controls on methane emissions from northern peatforming wetlands. Trends in Ecological Evolution 14: $385-388$. 
Kattenberg A, Giorgi F, Grassel H, Meehl GA, Michell JFB, Stoufer RJ, Tokioka T, Weaver AJ, Wigley TML. 1996. Climate models - projections of future climate. In Climate Change 1995, Houghton JT (ed.). University Press: Cambridge; 285-357.

Khalil MAK, Rasmussen RA, Shearer MJ. 1998. Effects of production and oxidation processes on methane emissions from rice fields. Journal of Geophysical Research 103: 25233-25239.

Liblik LK, Moore TR，Bubier JL，Robinson SD. 1997. Methane emissions from wetlands in the zone of discontinuous permafrost: Fort Simpson, Northwest Territories, Canada. Global Biogeochemical Cycles 11: 485-494.

Matthews E, Fung I. 1987. Methane emission from natural wetlands: global distribution, area, and environmental characteristics of sources. Global Biogeochemical Cycles 1: 61-86.

Morita RY. 1992. Low-temperature environments. In Encyclopedia of Microbiology, Vol. 2, Lederbetrg J (ed). Academic Press: San Diego; 625-637.

Morrissey LA, Livingston GP. 1992. Methane emissions from Alaska arctic tundra: an assessment of local special variability. Journal of Geophysical Research 97: $16661-16670$

Morrissey LA, Zobel DB, Livingston GP. 1993. Significance of stomatal control on methane release from Carex-dominated wetlands. Chemosphere 26: 339-355.

Müller K. 1997. Oberflächenstrukturen und Eigenschaften von Permafrostböden im nordsibirischen Lena-Delta. Zeitschrift für Pflanzenernährung und Bodenkunde 160: 497-503.

Nakano T, Kuniyoshi S, Fukuda M. 2000. Temporal variation in methane emission from tundra wetlands in a permafrost area, northeastern Siberia. Atmospheric Environment 34: 1205-1213.

Oberbauer SF, Starr G, Pop EW. 1998. Effects of extended growing and soil warming on carbon dioxide and methane exchange of tussock tundra in Alaska. Journal of Geophysical Research 103: 29 075-29 082.

Omelchenko MV, Vasilyeva LV, Zavarzin GA. 1993. Psychrophilic methanotrophs from tundra soils. Current Microbiology 27: 255-259.

Panikov NS, Dedysh SN. 2000. Cold season $\mathrm{CH}_{4}$ and $\mathrm{CO}_{2}$ emission from boreal peat bogs (West Siberia): winter fluxes and thaw activation dynamics. Global Biogeochemical Cycles 14: 1071-1080.

Pfeiffer E-M, Wagner D, Becker H, Vlasenko A, Kutzbach L, Boike J, Quass W, Kloss W, Schulz B, Kurchatova A, Pozdnyakov VI, Akhmadeeva I. 2000. Modern processes in permafrost affected soils. In Russian-German Cooperation System Laptev Sea 2000. The Expedition Lena 1999, Rachold V, Grigoriev MN (eds). Reports on Polar Research: AWI, Bremerhaven, $354 ; 22-54$.

Post WM, Emanuel WR, Zinke PJ, Stangenberger AG. 1982. Soil carbon pools and world life zones. Nature 298: $156-159$.

Reeburgh WS, King JY, Regli SK, Kling GW, Auerbach NA, Walker DA. 1998. A $\mathrm{CH}_{4}$ emission estimate for the Kuparuk River basin, Alaska. Journal of Geophysical Research 103: 29 005-29013.

Romanovskii NN, Hubberten H-W. 2001. Results of permafrost modelling of the lowlands and shelf of the Laptev Sea region, Russia. Permafrost and Periglacial Processes 12: 191-202.

Samarkin VA, Fedorov-Davydov DG, Vecherskaya MS, Rivkina EM. 1994. $\mathrm{CO}_{2}$ and $\mathrm{CH}_{4}$ emissions on cryosols and subsoil permafrost and possible global climate changes In Soil processes and greenhouse effect, Lal R, Kimble JM, Levine E (eds). USDA Soil Conservation Service, National Soil Survey Center, Lincoln, NE; $55-71$.

Samarkin VA, Gundelwein A, Pfeiffer E-M. 1999. Studies of methane production and emission in relation to the microrelief of a polygonal tundra in Northern Siberia. In Land-Ocean Systems in the Siberian Arctic, Kassens H, Bauch HA, Dmitrenko IA, Eicken H, Hubberten HW, Melles M, Thiede J, Timokhov LA (eds). Springer: Berlin; 329-342.

Schimel JP, Gulledge J. 1998. Microbial community structure and global trace gases. Global Change Biology 4: $745-758$.

Schwamborn G, Rachold V, Grigoriev MN. 2002. Late Quaternary sedimentation history of the Lena Delta. Quaternary International 89: 119-134.

Segers R. 1998. Methane production and methane consumption: a review of processes underlying wetland methane fluxes. Biogeochemistry 41: 23-51.

Slobodkin AI, Panikov NS, Zavarzin GA. 1992. Formation and uptake of methane in tundra and boreal wetlands. Microbiology 61: 683-691.

Soil Survey Staff. 1998. Keys to soil taxonomy. Eighth Edition. Soil Conservation Service, USDA: Washington, D.C.

Svensson BH, Rosswall T. 1984. In situ methane production from acid peat in plant communities with different moisture regimes in a subarctic mire. Oikos 43: 341-350.

Torn MS, Chapin III FS. 1993. Environmental and biotic controls over methane flux from Arctic tundra. Chemosphere 26: 357-368.

Tsuyuzaki S, Nakano T, Kuniyoshi S, Fukuda M. 2001. Methane flux in grassy marshlands near Kolyma River, north-eastern Siberia. Soil Biology and Biochemistry 33: $1419-1423$.

Van Bodegom P, Stams F, Mollema L, Boeke S, Leffelaar P. 2001. Methane oxidation and the competition for oxygen in the rice rhizosphere. Applied and Environmental Microbiology 67: 3586-3597.

Vecherskaya MS, Galchenko VF, Sokolova EN, Samarkin VA. 1993. Activity and species composition of aerobic methanotrophic communities in tundra soils. Current Microbiology 27: 181-184.

Verville JH, Hobbie SE, Chapin III FS, Hooper DU. 1998. Response of tundra $\mathrm{CH}_{4}$ and $\mathrm{CO}_{2}$ flux to manipulation of temperature and vegetation. Biogeochemistry 41: $215-235$.

Vourlitis GL, Oechel WC, Hastings SJ, Jenkins MA. 1993. The effect of soil moisture and thaw depth on $\mathrm{CH}_{4}$ flux 
from wet coastal tundra ecosystems on the north slope of Alaska. Chemosphere 26: 329-337.

Wagner D, Pfeiffer E-M, Bock E. 1999. Methane production in aerated marshland and model soils: effects of microflora and soil texture. Soil Biology and Biochemistry 31: 999-1006.

Wagner D， Spieck E， Bock E， Pfeiffer E-M. 2001. Microbial life in terrestrial permafrost: methanogenesis and nitrification in Gelisols as potentials for exobiological processes. In Astrobiology: the quest for the conditions of life, Horneck G, Baumstark-Khan C (eds). Springer: Berlin; 143-159.

Wein N. 1999. Sibirien. Perthes Regionalprofile. KlettPerthes. Gotha (in German).

Whalen SC, Reeburgh WS. 1988. A methane flux time series for tundra environments. Global Biogeochemical Cycles 2: 399-409.
Whalen SC, Reeburgh WS. 1992. Interannual variations in tundra methane emission: a 4-year time series at fixed sites. Global Biogeochemical Cycles 6: 139-159.

Whiting GJ, Chanton JP. 1992. Plant-dependent $\mathrm{CH}_{4}$ emission in a subarctic Canadian fen. Global Biogeochemical Cycles 6: 225-231.

Wuebbles DJ, Hayhoe K. 2002. Atmospheric methane and global change. Earth-Science Reviews 57: 177-210.

Yavitt JB, Williams CJ, Wieder RK. 2000. Controls on microbial production of methane and carbon dioxide in three Sphagnum-dominated peatland ecosystems as revealed by a reciprocal field peat transplant experiment. Geomicrobiological Journal 17: $61-88$. 